Отримано: 18 травня 2018 р.

Прорецензовано: 25 травня 2018 р.

Прийнято до друку: 29 травня 2018 р.

e-mail: kovalenko0202@ukr.net
Коваленко Ю. М. Місце, сутність і класифікаційні ознаки інвестиційних послуг у складі фінансових послуг. Наукові записки Національного університету «Острозька академія». Серія «Економіка» : науковий журнал. Острог : Вид-во НаУОА, червень 2018. № 9(37). С. 131-136.

Коваленко Юлія Михайлівна,

\title{
МІСЦЕ, СУТНІСТЬ І КЛАСИФІКАЦІЙНІ ОЗНАКИ ІНВЕСТИЦІЙНИХ ПОСЛУГ У СКЛАДІ ФІНАНСОВИХ ПОСЛУГ
}

У статті досліджено сутність фінансової послуги й операції, класифікація фінансових послуг за вітчизняними та міжнародними стандартами. Виокремлено інвестиційні послуги у складі фінансових послуг, подано їх авторське визначення. Розглянуто директиви ЄС, на основі чого визначено класифікаційні ознаки та види інвестиційних послуг.

Ключові слова: фінансові послуги, фінансові операції, фінансові інструменти, фінансові активи, інвестиційні послуги, інвестиційні фірми.

\section{Коваленко Юлия Михайловна, \\ доктор экономических наук, профессор кафедры финансовых рынков \\ Национального университета государственной фискальной службы Украины \\ МЕСТО, СУЩНОСТЬ И КЛАССИФИКАЦИОННЫЕ ПРИЗНАКИ ИНВЕСТИЦИОННЫХ УСЛУГ В СОСТАВЕ ФИНАНСОВЫХ УСЛУГ}

В статье исследуется сущность финансовой услуги и операџии, классификация финансовых услуг в отечественных и международных стандартах. Выделены инвестиционные услуги в составе финансовых услуг, представлено их авторское определение. Рассмотрены директивы EC, на основе чего определены классификационные признаки и виды инвестиционных услуг.

Ключевые слова: финансовые услуги, финансовые операчии, финансовые инструменты, финансовые активы, инвестиционные услуги, инвестициионные фирмыл.

\section{Yuliia Kovalenko, \\ Doctor of economics, professor of the department of financial markets \\ National University of the State Fiscal Service of Ukraine \\ LOCATION, ESSENCE AND CLASSIFICATION SIGNS OF INVESTMENT SERVICES IN FINANCIAL SERVICES}

The article examines the essence of the terms "financial service» and «financial operation», the classification of financial services according to domestic and international standards. The investment services are singled out in the structure of financial services, author's definition is given. The EU directives are considered and used as a basis for the classification of investment services features and types.

Key words: financial services, financial transactions, financial instruments, financial assets, investment services, investment firms.

Постановка проблеми. Зазвичай дослідження інвестиційних послуг входить до сфери інвестиційного ринку, зокрема сегменту інвестиційних товарів і послуг, або реального інвестування. Нині такий підхід можна вважати обмеженим, оскільки відповідно до вітчизняного законодавства [4], ринок цих послуг входить до складу ринку ринків фінансових послуг поряд із ринками банківських послуг, страхових послуг, операцій з цінними паперами й іншими видами ринків, що забезпечують обіг фінансових активів. За таких обставин нормативно-правова база України й інших країн світу має охоплювати весь спектр фінансової та страхової діяльності з орієнтацією на різних груп інвесторів. Задля цієї мети необхідно передбачити відповідний рівень гармонізації, що необхідна для забезпечення високого рівня захисту інвестора та надання фінансовим установам можливості надавати інвестиційні послуги.

Аналіз останнх досліджень і публікацій. Інвестиційному ринку, інвестиційній діяльності та пов'язаними 3 ними інвестиційними послугами присвячені роботи таких українських дослідників: 
О. Барановського, О. Вовчак, Р. Квасницької, В. Корнєєва, Д. Леонова, Б. Луціва, С. Льовочкіна, С. Онишко, С. Ревечука, В. Федосова, С. Хоружого, І. Школьник та інших. Зважаючи на значний світовий і європейський досвід у розробці новітніх фінансових інструментів, фінансових послуг, зокрема інвестиційних, низка питань, що пов'язані з сутністю цих послуг і їх класифікаційними ознаками, є недостатньо вивченими вітчизняними вченими та потребує подальшого дослідження теоретичних засад і практики виробництва інвестиційних послуг.

Метою статті є дослідження сутності фінансової й інвестиційної послуги, виокремлення класифікаційних ознак інвестиційних послуг за міжнародними стандартами.

Виклад основного матеріалу. Зазвичай визначення фінансової послуги випливає із нормативно-правової бази. Так, згідно зі ст. 1 Закону України «Про фінансові послуги та державне регулювання ринків фінансових послуг», фінансовою послугою ${ }^{1} \epsilon$ операції з фінансовими активами, що здійснюються в інтересах третіх осіб за власний рахунок чи за рахунок цих осіб, а у випадках, передбачених законодавством, - i за рахунок залучених від інших осіб фінансових активів, із метою отримання прибутку або збереження реальної вартості фінансових активів [4]. Мета фінансової операції, на нашу думку, - це отримання прибутку (доходу) i/або збереження реальної вартості фінансових активів. Трактування фінансової послуги потребує і конкретизації суб'єктів, які мають право виробляти ці послуги - фінансові установи, а у випадках, що передбачені законодавством, фізичні особи - суб'єкти підприємницької діяльності [2, с. 162].

До ринків фінансових послуг в Україні віднесено професійні послуги на ринках банківських послуг, страхових послуг, інвестиційних послуг, операцій із цінними паперами й інших видах ринків, що забезпечують обіг фінансових активів [4]. На відміну від національних стандартів, у Генеральній угоді з торгівлі послугами (ГАТС) [10] до фінансових послуг і відповідних ринків відносять ті, що наведені в таблиці 1. Д. Леонов, С. Льовочкін і С. Хоружий [3] роблять висновок про приблизне співпадіння видів цих послуг із визначеними законодавствамии країн із ефективними ринками фінансових послуг. Водночас вони звертають увагу на те, що «поняття фінансових ринків охоплює ринок банківських послуг, ринки фінансових інструментів з фіксованими доходами (облігації і грошові інструменти), ринки корпоративних цінних паперів та іноземної валюти, включаючи інфраструктуру щодо укладання та виконання угод із фінансовими інструментами, а також ринок послуг зі страхування» [3, с. 117]. На нашу думку, більш прийнятною є класифікація фінансових послуг на три групи: 1) страхові послуги та ті, що пов'язані зі страхуваням; 2) банківські послуги й інші фінансові послуги (окрім страхування); 3 ) інвестиційні послуги.

Власне, інвестиційні послуги як поняття виникли на Заході раніше за фінансові, їх пов'язують здебільшого з операціями на ринку цінних паперів. У США першими нормативно-правовими актами в цій сфері стали закони про банки (Banking Act, або загальновідомий закон Гласса-Стіголла, 1933), інвестиційні компанії (Investment Companies Act, 1940) та інвестиційних консультантів (Investment Advisers Act, 1940). Щодо інвестиційних послуг, то вони традиційно існують поряд із банківськими послугами, що передбачають прийняття грошових коштів вкладників і їх розміщення у вигляді позичкового капіталу [5, с. 37]. Розмежування цих двох груп послуг довгий час чинило вплив і на законодавства Японії та Південної Кореї.

Із поширенням інформаційних технологій у країнах із розмежуванням інвестиційних і банківських послуг стало відбуватись поступове відступання від Закону Гласса-Стіголла: як приклад - пошук компромісу між системами універсальних банківських послуг і розмежування банків на комерційні й інвестиційні, що були досягнуті в межах Директиви СЕС про інвестиційні послуги 1993 p. (Investment Services Directive). Ратифікація останньої в Свропі, а також реформи на ринках фінансових послуг країн Південно-Східної Азії спричинили прийняття Закону про модернізацію фінансових послуг (так званого Закону Гремма-Ліча-Блайлі, 1999), яким у США було надано дозвіл на банківські операції на ринках цінних паперів, а також на страхові послуги через дочірні компанії. Однак це торкнулося не універсальних банків, а універсальних банківських холдингів. Загалом із прийняттям закону Гремма-Ліча-Блайлі відбулася «легалізація» понять «фінансові послуги» та «фінансова діяльність» через застосування останніх у нормативно-правих актах США [6, с. 330].

${ }^{1}$ До фінансових послуг в Україні віднесено: 1) випуск платіжних документів, платіжних карток, дорожніх чеків та/ або їх обслуговування, кліринг, інші форми забезпечення розрахунків; 2) довірче управління фінансовими активами; 3) діяльність з обміну валют; 4) залучення фінансових активів із зобов'язанням щодо наступного їх повернення; 5) фінансовий лізинг; 6) надання коштів у позику, зокрема і на умовах фінансового кредиту; 7) надання гарантій і поручительств; 8) переказ коштів; 9) послуги у сфері страхування та в системі накопичувального пенсійного забезпечення; 10) професійна діяльність на ринку цінних паперів, що підлягає ліцензуванню; 11) факторинг; 11-1) адміністрування фінансових активів для придбання товарів у групах; 12) управління майном для фінансування об'єктів будівництва та/або здійснення операцій із нерухомістю відповідно до Закону України «Про фінансово-кредитні механізми і управління майном при будівництві житла та операціях з нерухомістю»; 13) операції з іпотечними активами з метою емісії іпотечних цінних паперів; 14) банківські й інші фінансові послуги, що надаються відповідно до Закону України «Про банки і банківську діяльніст» [6]. 
Класифікація фінансових послуг у Генеральній угоді з торгівлі послугами

Види та підвиди
1. Страхові послуги та ті, що пов'язані зі страхуванням

(i) Пряме страхування (зокрема спільне страхування):

(A) життя

(B) крім страхування життя

(ii) Перестрахування і ретроцесія

(iii) Страхове посередництво, таке як брокерське й агентське

(iv) Допоміжні послуги зі страхування, такі як консультаційні, актуарні послуги, оцінка ризику та послуги з урегулювання претензій

2. Банківські послуги й інші (окрім страхування)

(v) Прийняття депозитів та інших грошових коштів від населення

(vi) Видача позичок усіх видів, зокрема споживчого кредиту, кредиту під заставу, факторинг і фінансування комерційних операцій

(vii) Фінансовий лізинг

(viii) Усі види послуг щодо платежів і грошових переказів, зокрема з включенням кредитних, платіжних і дебетових карток, дорожніх чеків і банківських векселів

(ix) Гарантії і зобов'язання

(х) Торговельні операції за власний рахунок чи за рахунок клієнтів, на валютній біржі, на позабіржовому ринку, або в інший спосіб:

(А) інструментами грошового ринку (чеки, переказні векселі, депозитні сертифікати);

(В) іноземною валютою;

(C) похідними продуктами, зокрема, але не виключно ф'ючерсами й опціонами;

(D) інструментами, що мають відношення до валютних курсів і відсоткових ставок, зокрема угоди про свопи та форвардні угоди про відсоткові ставки

(Е) переказними цінними паперами;

(F) іншими інструментами та фінансовими активами, що можуть бути предметом угоди, зокрема золото та срібно у зливках

(хі) Участь в емісіях усіх видів цінних паперів, зокрема організацію підписки та

розміщення у якості агента (через публічну або закриту підписку), та надання послуг, що належать до таких випусків

(хіi) Брокерські операції на грошовому ринку

(хіiі) Управління активами, такими як готівка або портфель цінних паперів, всі форми управління колективними інвестиціями, управління пенсійним фондом, послуги з відповідального зберігання, депозитарні та трастові послуги

(xiv) Послуги із взаємозаліків та клірингові послуги щодо фінансових активів, зокрема цінні папери, похідні продукти та інші інструменти, що можуть бути предметом угоди

(xv) Надання та передача фінансової інформації, обробка фінансових даних і відповідного програмного забезпечення постачальників інших фінансових послуг

(xvi) Консультації, посередництво й інші допоміжні фінансові послуги в усіх видах діяльності, що перераховані в пунктах (v)-(xv), зокрема надання довідникових і матеріалів у зв'язку з кредитуванням і кредитний аналіз дослідження, рекомендації з прямих і портфельних інвестицій, придбання, реорганізації та стратегії корпорацій

Джерело. Складено на основі [10].

У Європі створення єдиного ринку інвестиційних послуг пов'язують із ухваленням Директиви 85/611/ EЕС «Про узгодження законів, нормативно-правових та адміністративних положень, що стосуються установ колективного інвестування в цінні папери, що підлягають обігу» [9], яка заклала підвалини гармонізації умов ліцензування діяльності та пруденційного нагляду за діяльністю певних фінансових установ, а згодом і Директиви 2004/39/EU «Про ринки фінансових інструментів» [7]. Водночас остання світова фінансова криза наочно продемонструвала слабкі боки функціонування та прозорості ринків фінансових послуг, що затребувало зміцнення основ їх регулювання з метою захисту інвесторів, підвищення довіри, а також надання наглядовим органам відповідних повноважень для виконання їх функцій та поставлених завдань. Наслідком стало прийняття Директиви 2014/65/EU «Про ринки фінансових інструментів» [8], якою вносяться також зміни у Директиву 2002/92/EU і Директиву 2011/61/ EU, а її метою декларується охоплення підприємств із постійним родом занять або постійною діяльністю з наданням інвестиційних послуг і (або) веденням інвестиційної діяльності на професійній основі [8]. Інвестиційними послугами й інвестиційною діяльністю є будь-які з видів послуг або діяльності, що зазначені в розділі А Додатку 1 Директиви 2014/65/ EU (таблиця 2), щодо будь-якого з інструментів , що зазначені в розділі С цього ж додатку (таблиця 3). 
Перелік послуг і видів діяльності в Директиві 2014/65/EU

\begin{tabular}{|c|c|c|c|}
\hline $\begin{array}{l}\text { № } \\
\text { 3/II }\end{array}$ & $\begin{array}{c}\text { Розділ А. Інвестиційні послуги } \\
\text { та види діяльності } \\
\end{array}$ & $\begin{array}{l}\text { № } \\
\text { 3/II }\end{array}$ & Розділ В. Допоміжні послуги \\
\hline 1 & $\begin{array}{l}\text { Приймання/передача замовлень } \\
\text { щодо одного і більше фінансових } \\
\text { інструментів }\end{array}$ & 1 & $\begin{array}{l}\text { Послуги щодо зберігання й управління фінансовими інструментами для } \\
\text { обліку клієнтів (зокрема послуги із зберігання цінностей), а також спо- } \\
\text { ріднені послуги (зокрема управління готівкою або забезпеченням) за ви- } \\
\text { ключенням послуг із ведення рахунків у цінних паперах на вищому рівні }\end{array}$ \\
\hline 2 & $\begin{array}{l}\text { Виконання замовлень від імені } \\
\text { клієнтів }\end{array}$ & 2 & $\begin{array}{l}\text { Видача кредитів/позик інвестору з метою дозволу здійснення трансакції } \\
\text { одним або кількома фінансовими інструментами у випадках, де у трансакції } \\
\text { бере участь фірма, яка видає кредит/позику }\end{array}$ \\
\hline 3 & $\begin{array}{l}\text { Здійснення операцій за свій } \\
\text { рахунок }\end{array}$ & 3 & $\begin{array}{l}\text { Консультаційні послуги компаніям щодо структури капіталу, промислової } \\
\text { стратегії і тощо, послуги, що пов'язані зі злиттями та купівлею компаній }\end{array}$ \\
\hline 4 & Портфельне управління & 4 & Послуги з обміну валюти, що пов'язані з інвестиційними послугами \\
\hline 5 & Інвестиційне консультування & 5 & $\begin{array}{l}\text { Дослідження у сфері інвестиційної діяльності, фінансовий аналіз, інші фор- } \\
\text { ми загальних рекомендацій щодо операцій із фінансовими інструментами }\end{array}$ \\
\hline 6 & $\begin{array}{l}\text { Передплата на фінансові інстру- } \\
\text { менти та/або розміщення фінан- } \\
\text { сових інструментів на основі } \\
\text { твердого зобов'язання }\end{array}$ & 6 & Послуги, що пов'язані з андерайтингом \\
\hline 7 & $\begin{array}{l}\text { Розміщення фінансових інстру- } \\
\text { ментів не на твердому зобов'язанні }\end{array}$ & 7 & $\begin{array}{l}\text { Інвестиційні послуги та діяльність, додаткові послуги за типами послуг, які до- } \\
\text { лучено до розділу А або В додатку } 1 \text {, що пов'язані з основними деривативами }\end{array}$ \\
\hline 8 & $\begin{array}{l}\text { Управління багатосторонніми тор- } \\
\text { говельними майданчиками (БТМ) }\end{array}$ & & \\
\hline 9 & $\begin{array}{l}\text { Управління організованими } \\
\text { торговельними майданчиками } \\
\text { (ОТМ) }\end{array}$ & & \\
\hline
\end{tabular}

Джерело. Складено на основі [8].

\section{Перелік фінансових інструментів у Директиві 2014/65/EU}

\begin{tabular}{|c|c|}
\hline 1 & Цінні папери в обігу \\
\hline 2 & Інструменти ринку грошей \\
\hline 3 & Паї установ колективного інвестування \\
\hline 4 & $\begin{array}{l}\text { Опціони, ф’ючерси, свопи, угоди за форвардними відсотковими ставками, інші контракти на деривативи, які пов'язані } \\
3 \text { цінними паперами, валютними цінностями, ставками відсотка або дохідністю, квотами на викиди, іншими дери- } \\
\text { вативами, фінансовими показниками або фінансовими заходами із здійсненням фізичних і готівкових розрахунків }\end{array}$ \\
\hline 5 & $\begin{array}{l}\text { Опціони, ф’ючерси, свопи, угоди за форвардними відсотковими ставками, інші контракти на деривативи, які } \\
\text { пов'язані з товарами, де розрахунки мають бути здійснені готівкою або готівкою за вибором однієї зі сторін (окрім } \\
\text { невиконання зобов’язань або іншого припинення подій) }\end{array}$ \\
\hline 6 & $\begin{array}{l}\text { Опціони, ф'ючерси, свопи, угоди за форвардними відсотковими ставками, інші контракти на деривативи, які пов'язані } \\
3 \text { товарами з фізичними розрахунками за умови, що торгівля ними провадиться на регульованому ринку, БТМ або } \\
\text { ОТМ (окрім оптових енергетичних товарів з торгівлею на ОТМ і за якими мають здійснюватись фізичні розрахунки) }\end{array}$ \\
\hline 7 & $\begin{array}{l}\text { Опціони, ф’ючерси, свопи, угоди за форвардними відсотковими ставками, інші контракти на деривативи, які } \\
\text { пов'язані з товарами з фізичними розрахунками, та які не використовують із комерційною метою, мають власти- } \\
\text { вості інших деривативів }\end{array}$ \\
\hline 8 & Деривативи із передачею кредитного ризику \\
\hline 9 & Фінансові інструменти на різницю \\
\hline 10 & $\begin{array}{l}\text { Опціони, ф'ючерси, свопи, угоди за форвардними відсотковими ставками, інші контракти на деривативи, які пов'язані } \\
3 \text { кліматичними змінами, фрахтовими ставками чи інфляційними ставками, іншими офіційними економічними ста- } \\
\text { тистичними показниками, розрахунки за якими здійсненюються готівкою або готівкою за вибором однієї зі сторін, } \\
\text { окрім через невиконання зобов'язання або іншого припинення події, інші контракти на деривативи щодо активів, прав, } \\
\text { обов'язків, індеків і заходів, що мають властивості інших деривативів з обігом на регульованому ринку, ОТМ або БТМ }\end{array}$ \\
\hline 11 & $\begin{array}{l}\text { Емісії на викиди із будь-яких одиниць, що визнані вимогами Директиви 2003/87/EC, зокрема Схемою торгівлі } \\
\text { викидами }\end{array}$ \\
\hline
\end{tabular}

Джерело. Складено на основі [8].

* БТМ - це багатостороння система, якою управляє інвестиційна фірма або оператор ринку, що об єднує численні інтереси третіх сторін із купівлі-продажу фінансових інструментів - у цій системі і за їі недискреційними правилами - або сприяє поєднанню зазначених інтересів з метою укладення контракту .ОТМ - це багатостороння система, яка не виконує роль регульованого ринкку або БТМ, і у якій різноманітні інтереси третіх осіб у частині купівлі-продажу облігацій, структурованих фінансових продуктів, квот на викиди або деривативів приведуть до укладання контракту [8]. 
Проведене дослідження дає нам змогу визначити інвестиційні послуги як операції з фінансовими інструментами на ринках фінансових послуг, зокрема інвестиційних, що виробляються суб'єктами, постійний рід занять або постійна діяльність яких полягає у виробництві таких послуг i/або провадженні інвестиційної діяльності на професійній основі, в інтересах професійних або роздрібних клієнтів за власний рахунок або за рахунок цих осіб, а у випадках, що передбачені законодавством, - за рахунок залучених від інших осіб фінансових активів, із метою одержання доходу i/або збереження реальної вартості таких активів. Ці послуги можна класифікувати за такими ознаками:

1. За способом реалізації: а) виконання замовлень від імені клієнта - діяльність щодо укладання різноманітних угод щодо купівлі-продажу одного або кількох фінансових інструментів від імені клієнта (зокрема, укладання угод щодо продажу фінансових інструментів, які випущені інвестиційною або кредитною установою, у момент випуску цих інструментів); б) здійснення операцій за власний рахунок;

2. За типом виробника: а) інвестиційна фірма, яка $є$ юридичною особою, яка за постійним родом занять чи постійною діяльністю надає одну чи декілька інвестиційних послуг третім особам i/або провадить один чи декілька видів інвестиційної діяльності, що базуться на професійній основі; б) інвестиційна фірма, яка є неюридичною особою, за умови, що 1) ії правовим статусом забезпечується відповідний захист інтересів третіх осіб, що є еквівалентним рівню захисту юридичної особи; 2) вона підпадає під відповідний пруденційний контроль згідно з організаційно-правовою формою; б) пов'язаним агентом $\epsilon$ фізична або юридична особа з повною та безумовною відповідальністю винятково однієї інвестиційної фірми, від імені якої вона виступає, сприяє виробництву інвестиційних і (або) додаткових послуг клієнту або потеційному клієнту, одержує і передає розпорядження чи замовлення від імені клієнта щодо інвестиційних послуг або фінансових інструментів, розміщує останні чи консультує клієнта чи можливого клієнта щодо фінансових інструментів або інвестиційних послуг [8]; в) управляюча компанія - компанія, що управляє активами інвестиціної фірми; г) фізична особа - за умови, що вона виробляє послуги щодо зберігання коштів або цінних паперів в обігу із приналежністю третім особам;

3. За типом клієнта: а) професійний клієнт - клієнт із досвідом, знаннями й експертизою, який приймає власні інвестиційні рішення і правильно оцінює свої ризики²; б) роздрібний клієнт - клієнт, який не $\epsilon$ професійним;

4. За інструментами реалізації з: а) цінними паперами в обігу; б) інструментами грошового ринку; в) паями установ колективного інвестування; г) опџіонами, ф'ючерсами, свопами, угодами з форвардними процентними ставками; д) емісіями на викиди, які включають будь-які одиниці, що визнані вимогами Директиви 2003/87/EC;

5. За торговельним майданчиком: а) на регульованому ринку - уповноваженій і регулярно функціонуючій багатосторонній системі, яка обслуговується i/або управляється оператором ринку, акумулює різні інтереси третіх сторін із купівлі-продажу фінансових інструментів - у цій системі і за ії недискреційними правилами - або всебічно поєднаную такі інтереси з метою укладання контракту щодо фінансових інструментів, які допущені до обігу за ії правилами та/або системи [8]; б) на багатосторнньому торговельному майданчику (БТМ); в) на організованому торговельному майданчику (ОТМ);

6. За типом торгівлі: а) зустрічна торгівля за власний рахунок, де між покупцем і продавцем за цією угодою діє посередник, який за жодних обставин не повинен піддаватися ринковому ризику за весь період здійснення такої операції. Обидві сторони угоди реалізуються одночасно, а сама угода - за такою ціною, де посередник не отримує прибутку або збитку, а лише попередньо узгоджену комісію, збір чи тариф за цією операцією; б) алгоритмічна торгівля - торгівля фінансовими інструментами, де автоматично комп'ютерним алгоритмом (обмежене втручання людини чи взагалі без втручання) визначаються специфічні параметри замовлень (наприклад, необхідність надання замовлення, його термін, ціна, обсяг чи порядок виконання після надання), за винятком системи, що використовується лише для відправлення замовлень на торговельні майданчикики, оброблення замовлення без встановлення параметрів торгівлі чи їх підтвердження, оброблення результатів виконаних операцій [8];

7. За диференціацією задоволення потреб клієнта: а) прямі продажі - задоволення наявних потреб клієнта; б) перехресні продажі - пропонування послуги як пакету з іншими послугами, продуктами або як умова для цієї самої угоди чи пакету;

${ }^{2}$ Для того, щоб бути професійним клієнтом, клієнт повинен відповідати таким критеріям: 1) наявність дозволу або його діяльність підлягає регулюванню на фінансовому ринку: а) кредитні установи; b) інвестиційні компанії; с) інші фінансові установи, які $є$ уповноваженими або регульованими; d) страхові компанії; е) схеми з колективного інвестування та їx компанії з управління активами; f) пенсійні фонди та їх компанії з управління активами; g) дилери $з$ товарів і товарних деривативів; h) компанії місцевого ринку; i) інші установи, які є інституційними інвесторами; 2) великі підприємства за двома із таких критеріїв: валюта балансу - 20 млн євро; чистий товарооборот - 40 млн євро; власні кошти - 2 млн євро; 3 ) національні та регіональні органи влади з включенням державних органів влади, що здійснюють управління державним боргом на національному чи регіональному рівні, центральний банк, міжнародні та наднаціональні установи; 4) інші інституційні інвестори, які інвестують у фінансові інструменти, а також особи, які займаються сек'юритизацією активів та інших фінансових угод [8]. 
8. За рухом фінансових активів: а) послуги, виробництво ${ }^{3}$ яких супроводжується рухом фінансових активів; б) послуги, які виробляються без зазначеного руху (допоміжні послуги у сфері інвестиційних послуг і видів діяльності);

9. За тривалістю та метою послуги: а) стратегічні - дозволяють клієнту розробити та досягти суттєвих стратегічних трансформацій у характері, напрямах і масштабах своєї діяльності чи способі життя; б) поточні - націлені на досягнення мети клієнта на рік у найоптимальніший спосіб; в) оперативні - дозволяють клієнту підготуватися і швидко розв'язати незаплановані проблеми.

Висновки. Отже, проведене дослідження дало змогу визначити, що фінансові послуги можна класифікувати на: а) страхові та ті, що пов'язані зі страхуваням; б) банківські й інші фінансові послуги (крім страхування); в) інвестиційні. Своєю чергою, інвестиційні послуги - це операції з фінансовими інструментами на ринках фінансових послуг, що виробляються суб'єктами з постійним родом занять або постійною діяльністю, яка полягає у виробництві таких послуг i/або провадженні інвестиційної діяльності на професійній основі, в інтересах професійних або роздрібних клієнтів за власний рахунок або за рахунок цих осіб, а у випадках, що передбачені законодавством, - за рахунок залучених від інших осіб фінансових активів, із метою отримання доходу i/aбо збереження реальної вартості фінансових активів. Їх можна класифікувати за виокремленими ознаками, що відповідають міжнародним стандартам. В Україні в частині інвестиційних послуг необхідно передбачити відповідний рівень гармонізації з міжнародними та європейськими стандартами, що необхідна для підвищення захисту інвестора та дозволу фінансовим установам можливості надавати ці послуги.

\section{Література:}

1. Коваленко Ю.М. Теоретичні аспекти послуги та їі види. Вісник Київського національного торговельноекономічного університету. 2012. № 2. С. 38-46.

2. Коваленко Ю.М. Фінансові послуги: сутність та класифікація. Світ фінансів. 2012. Вип. 3.С. 162-169.

3. Леонов Д., Льовочкін С., Хоружий С. Ринок фінансових послуг: парадигма євроінтеграції: монографія / за наук. ред. В. М. Федосова. К.: УІРФР, 2008. 848 с.

4. Про фінансові послуги та державне регулювання ринків фінансових послуг: Закон України: від 12.07.01 p. № 2664. URL: zakon.rada.gov.ua/cgi-bin/laws/main.cgi?nreg=2664-14 (Last accessed: 21.05.2018).

5. Розвиток фінансових посередників у турбулентних умовах функціонування національної економіки: кол. монографія / за заг. ред. В. П. Ільчука. Чернігів: ЧНТУ, 2017. 200 с.

6. Становлення економіки України у післякризовий період: ризики та проблеми розвитку: кол. монографія / за ред. О. О. Непочатенко. Ч. 1. Умань: Видавець «Сочинський», 2012. 416 с.

7. On markets in financial instruments amending: Directive of the European Parliament and of the Council: of 21.04.04 № 2004/39/EC. URL: http://www.mifidirective.com/mifid-directive.pdf (Last accessed: 15.05.2018).

8. On markets in financial instruments and amending: Directive of the European Parliament and of the Council: of 15.05.14 №2014/65/EU (Directive 2002/92/EC and Directive 2011/61/EU). URL: http://www.eufsp.com/laws.html (Last accessed: 16.05.2018).

9. On the coordination of laws, regulation and administrative provisions relating to undertakings for collective investment in transferable securities (UCITS): Council Directive: of 20.12.85 № 85/611/EEC. URL: http://www. esma.europa.eu/system/files/Dir_85_611.PDF (Last accessed: 15.05.2018).

10. World Trade Organization. General Agreement on Trade in Services (GATS). URL: https://www.wto.org/ english/tratop_e/serv_e/gatsintr_e.htm (Last accessed: 14.05.2018).

\footnotetext{
${ }^{3}$ Термін «виробництво» стосуєтьсясьогодні і сфери послуг, а продукція є результатом економічної діяльності і загальним терміном, який використовується як для позначення товарів, так і послуг [1, с. 42$]$.
} 